\title{
The Effect of Using the Numbered Heads Strategy for Development of Mathematical Concepts and Visual Thinking Skills in Mathematics for Students of the Second Intermediate Grade in Madinah
}

\author{
Mansour A. Alblady and Ayman A. Mamdoh
}

Faculty of Education, Al-Madinah International University, Malaysia

\begin{abstract}
The aim of the research was to reveal the effect of using the Numbered Heads strategy in developing mathematical concepts and visual thinking skills in mathematics among second grade students in the Madinah.In order to achieve the research objective, the researcher used the semi-experimental method. He applied the research to a sample of (52) second grade students in Medina in the first semester of 1437/1438 H (2017). They were divided into two groups: one was experimental and used the Numbered Heads strategy, and the other studied in the usual way. To achieve the objectives of the research, a test of mathematical concepts was used as well as a test of visual thinking skills. The researcher taught the two groups, and after conducting the necessary statistical processing, the research concluded that:There are statistically significant differences at the level of $(\alpha \leq 0.05)$ between the average scores of the students in the experimental group and the control group in the post-application of the test of mathematical concepts. These differences were in favor of the average score of the students in the experimental group, There are statistically significant differences at the level of $(\alpha \leq 0.05)$ between the average scores of the students in the experimental group and the control group in the post-application of the test of visual thinking (visual reading, interpretation, linking, analysis, deduction, and total). All differences were in favor of the experimental group,In light of the research findings, the researcher recommended using the Numbered Heads strategy in teaching the content of different subjects in public education institutions and holding training courses for mathematics teachers to teach them how to use the Numbered Heads strategy in developing mathematical concepts, as well as paying attention to visual training for students at all
\end{abstract}

Keywords: Numbered Heads Strategy; Mathematical Concepts; Visual Thinking Skills

Citation: Alblady, M\& Mamdoh, A, The Effect of Using the Numbered Heads Strategy for Development of Mathematical Concepts and Visual Thinking Skills in Mathematics for Students of the Second Intermediate Grade in Madinah, SVU-Journal of abstract 2020, 2(1): pp1 (retrieved from the SVU- International Journal Of Educational Sciences,2020, No 4).

Copyright: Publisher South Valley University. This is an open access article distributed under the terms of the creative common attribution license, which permits unrestricted use, distribution and reproduction in any medium provided the original author and source are created. 